\title{
GENETIC DIVERSITY ANALYSIS OF THE FIRST AND SECOND GENERATIONS OF FAST- GROWING STRIPED CATFISH (Pangasianodon hypophthalmus Sauvage,1878) USING MICROSATELLITE ANALYSIS
}

\author{
Huria Marnis\#, Evi Tahapari, and Jadmiko Darmawan \\ Research Institute for Fish Breeding \\ (Received 7 December 2017; Final revised 12 February 2018; Accepted 12 February 2018)
}

\begin{abstract}
Genetic diversity is an important aspect of a selective breeding program to produce fish broodstock carrying superior traits such as fast-growing, disease resistant, and other traits. We have carried out a breeding program to produce a fast-growing striped catfish (Pangasianodon hypophthalmus) since 2010. The aim of this study was to evaluate the genetic variation of the first (G-1) and second (G-2) generations of fastgrowing striped catfish using microsatellite analysis. The G-1 and G-2 populations were selected individually from populations. DNA samples were collected from 40 ind. fish of each population and analyzed using five microsatellite loci (Pg1, Pg2, Pg3, Pg13, and Pg14). The results showed that the number of alleles per loci in the G-1 and G2 populations ranged from 4 to 7 alleles, with an average of five for each generation. The average of observed heterozygosity of the G-1 population (0.420) was lower than the G-2 population $(0.495)$. Inbreeding level showed that the G-1 population was more inbred than the G-2 population. The study also found that both striped catfish populations had relatively low genetic variation. This result suggests that monitoring of genetic variation and better scheme of good spawning were needed on the next selection program to produce the intended fast-growing striped catfish.
\end{abstract}

\section{KEYWORDS: genetic; microsatellite; Pangasianodon; catfish}

\section{INTRODUCTION}

Worldwide aquaculture production has increased considerably during the last four decades and surpassed capture fisheries in terms of fish supply for human consumption (FAO, 2016). It is expected that aquaculture production will continue to increase further in the future, particularly the fish production from freshwater aquaculture. Striped catfish (Pangasianodon hypophthalmus), or locally referred to as "patin siam" in Indonesia is an important freshwater aquaculture commodity in the Southeast Asia country such as Vietnam (Bui et al., 2010), Indonesia (Directorate of Aquaculture, 2016) and Thailand (Na-Nakorn \& Moeikum, 2009).

Various studies have been done to optimize striped catfish production. However, information related to the genetic diversity of striped catfish popu-

\footnotetext{
\# Correspondence: Research Institute for Fish Breeding. Jl. Raya Sukamandi No. 2, Subang 41256, Indonesian. Phone: + 62260520500

E-mail: marnis.huria@gmail.com
}

lations is currently limited. According to Hughes et al. (2008), genetic diversity is an important aspect of a population dynamics, because it is directly related to the evolutionary potential of the population and the deleterious effects of inbreeding.

Among molecular genetic methods, microsatellite represents the most widely applicable DNA technology for determining genetic diversity. Microsatellites are short stretches (tens to hundreds of base pairs) of DNA composed of di-tri, or tetranucleotide repeats arrayed in tandem (Park \& Moran, 1994). They have been shown to be highly polymorphic in teleost fish (Zane et al., 2002; Das et al., 2005; and Chistiacov et al., 2005) and in striped catfish (Na-Nakorn et al., 2006; So et al., 2006; Na-Nakorn \& Moeikum, 2009; and $\mathrm{Ha}$ et al., 2009).

The aim of this study was to evaluate the genetic variation of the first (G-1) and second (G-2) populations of fast-growing striped catfish using microsatellite analysis. 


\section{MATERIALS AND METHODS}

\section{Fish and Sample Collections}

The samples consisted of the G-1 and G-2 populations of fast-growing striped catfish. A total of 40 fish was sampled from each population at the Research Institute for Fish Breeding. Approximately 1 $\mathrm{cm}^{2}$ of the caudal fin tissue was extracted from the fish and placed into a microtube containing $1 \mathrm{~mL}$ of $70 \%$ alcohol and stored at room temperature for the subsequent DNA extraction process.

\section{DNA Extraction}

Genomic DNA of each sample was extracted using DNA extraction kit (Genejet Genomic DNA Purification) following the protocols recommended by the manufacturer (Thermo Scientific, Lithuania). Briefly, the protocol consisted of series of steps including cell lysis, DNA precipitation, binding DNA to the column, washing, and elution. Cell lysis was performed by weighing of approximately $10 \mathrm{mg}$ of a tissue sample. In order to check if the genomic DNA extraction process had been successful, the samples were tested on a mini horizontal gel electrophoresis system. In the test, the sample was loaded into a $1.5 \%(\mathrm{w} / \mathrm{v})$ agarose gel and the system was powered by 65 -volt electricity for 60 minutes. The gel was then stained with peqGREEN (Vwr, UK) $1 \mu \mathrm{g} / \mathrm{mL}$ and viewed using ultraviolet transilluminator gel documentation system.

\section{Microsatellite Primers}

Five microsatellite loci Pg1, Pg2, Pg3, Pg13, and Pgl4 showing polymorphisms in Pangasianodon hypophthalmus were used in this study (Na-Nakorn et al., 2006 and Na-Nakorn \& Moeikum, 2009). The primers' characteristics used to amplify the five microsatellite loci are presented in Table 1.

\section{Amplification of Microsatellite Loci and Scoring}

A total of $2 \mu \mathrm{L}$ (d" $200 \mathrm{ng}$ ) of each extracted genomic DNA was amplified using type-it microsatellite PCR (Qiagen). The PCR process was programmed as follows: $95^{\circ} \mathrm{C}$ for five minutes; $\left(95^{\circ} \mathrm{C}\right.$ for 30 seconds, $6^{\circ} \mathrm{C}-62^{\circ} \mathrm{C}$ for 90 seconds according to the degree of the attaching temperature (Tm) per primer (Table 1); $72^{\circ} \mathrm{C}$ for 30 seconds) of 28 cycles; and $72^{\circ} \mathrm{C}$ for 30 minutes. The PCR amplification results were loaded on $2 \%(\mathrm{w} / \mathrm{v})$ agarose gel using an electrophoresis method. The electrophoresis results were observed under UV transilluminator and photographed using a Canon EOS 1100D digital camera.

Microsatellite locus polymorphisms were screened using the QIAxcel (Qiagen) fragment analyzer and QIAxcel DNA High-resolution kit (Qiagen). The size of the alleles was determined based on PCR product size relative to the size of the DNA fragment on QX size marker 50-800 bp (Qiagen) and alignment marker 50-1,000 bp (Qiagen). Patterns of DNA band and electrophoregram data were analyzed using QIAxcelscreenGel software 1.5 (Qiagen) to define the microsatellite alleles. The allele score data were then used for the analysis of relevant genetic parameters.

\section{Data Analysis}

The observed allele data were processed using Microsoft Excel program. Parameters of genetic variability include a number of alleles (A), allele frequency, observed heterozygosity ( $\mathrm{Ho}$ ) and expected (He), Hardy-Weinberg equilibrium (HW), and fixation index (FIS) were analyzed using Fstat's statistical genetic software version 2.9.3. (Goudet, 2001). Genetic variations within and between populations were analyzed using AM OVA (Analysis of Molecular Variance) found in Arlequin software (Excoffier et al., 2006).

Table 1. Attributes of microsatellite primers used to amplify polymorphic microsatellite alleles in the G-1 and G-2 striped catfish populations

\begin{tabular}{c|c|c|c|c}
\hline Loci & Motif & Primer sequence (5'-3') & Range size (bp) & Tm (') \\
\hline Pg1 & $(\mathrm{CA})_{18}$ & $\begin{array}{l}\text { F: GGCCTGTCACAATGTGTATTGC } \\
\text { R: GTCTGAGGTAGGCCTGTGAGGAG }\end{array}$ & $231-239$ & 64 \\
\hline Pg2 & $(\mathrm{GA})_{14} \mathrm{~N}_{116}(\mathrm{GT})_{11}$ & $\begin{array}{l}\text { F: TGTGTCTAATCTTGTCCGTGCTG } \\
\text { R: TACTGTTGGACCAGACGTTCCTC }\end{array}$ & $258-276$ & 60 \\
\hline Pg3 & $(\mathrm{GT})_{16}$ & $\begin{array}{l}\text { F:CCAGCCCACATTAGGTAGCATC } \\
\text { R: ACTAAAAGGCCTGACCCTTAGC }\end{array}$ & $204-220$ & 60 \\
\hline Pg13 & $(\mathrm{CA})_{25}$ & $\begin{array}{l}\text { F: GTTTTCCATCCAGGTTGTTTTCC } \\
\text { R: TAAGTCCATGTGGGTTTCCTCTG }\end{array}$ & $232-262$ & 58 \\
\hline Pg14 & $\begin{array}{c}(\mathrm{GT})_{5} A T(G T)_{11} \\
\mathrm{AT}(\mathrm{GT})_{13}\end{array}$ & $\begin{array}{l}\text { F: ACCGTGCATGTGCATTATCATAG } \\
\text { R: AGAATGTGACCTGGAAATGAGCA }\end{array}$ & $289-293$ & 60 \\
\hline
\end{tabular}




\section{RESULTS AND DISCUSSION}

\section{Polymorphic of Microsatellite Locus}

The results of microsatellite analysis on the G-1 and G-2 of striped catfish were presented in Table 2. It showed that the five primers used in this study enabled to amplify and produced polymorphic loci. A total of 25 different alleles were obtained with sizes ranging from $192 \mathrm{bp}$ to $291 \mathrm{bp}$. The number of alleles identified in this study was less than the previous study by Na-Nakorn et al. (2006), who reported that 28 alleles were obtained using the same primers.

Each locus had 4-7 alleles whereby the highest number of alleles was detected at the Pgl locus with

Table 2. Genetic variability of five microsatellite loci in the G-1 and G-2 populations of fast-growing striped catfish

\begin{tabular}{|c|c|c|c|}
\hline \multirow{2}{*}{ Loci } & \multirow{2}{*}{ Parameters } & \multicolumn{2}{|c|}{ Population } \\
\hline & & G-1 & G-2 \\
\hline \multirow{7}{*}{ Pg1 } & Allele size range (bp) & $218-242$ & $218-242$ \\
\hline & Number of sample (N) & 40 & 40 \\
\hline & Number of allele (A) & 7 & 7 \\
\hline & Observed heterozygosity (Ho) & 0.975 & 0.95 \\
\hline & Expected heterozygosity (He) & 0.800 & 0.808 \\
\hline & Fixation index (Fis) & -0.221 & -0.178 \\
\hline & p-value of Hardy-Weinberg (HW) & 0.003 & 0.000 \\
\hline \multirow{7}{*}{$\mathrm{Pg} 2$} & Allele size range (bp) & $230-240$ & $230-240$ \\
\hline & Number of sample (N) & 40 & 40 \\
\hline & Number of allele (A) & 5 & 5 \\
\hline & Observed heterozygosity (Ho) & 0.400 & 0.700 \\
\hline & Expected heterozygosity (He) & 0.750 & 0.790 \\
\hline & Fixation index (Fis) & 0.471 & 0.115 \\
\hline & p-value of Hardy-Weinberg (HW) & 0.000 & 0.000 \\
\hline \multirow{7}{*}{$\mathrm{Pg} 3$} & Allele size range (bp) & $192-206$ & $192-206$ \\
\hline & Number of sample $(\mathrm{N})$ & 40 & 40 \\
\hline & Number of allele (A) & 4 & 4 \\
\hline & Observed heterozygosity ( $\mathrm{Ho})$ & 0.125 & 0.325 \\
\hline & Expected heterozygosity (He) & 0.567 & 0.564 \\
\hline & Fixation index (Fis) & 0.782 & 0.427 \\
\hline & p-value of Hardy-Weinberg (HW) & 0.000 & 0.000 \\
\hline \multirow{7}{*}{$\operatorname{Pg} 13$} & Allele size range (bp) & $227-233$ & $227-233$ \\
\hline & Number of sample (N) & 40 & 40 \\
\hline & Number of allele (A) & 4 & 4 \\
\hline & Observed heterozygosity $(\mathrm{Ho})$ & 0.05 & 0.05 \\
\hline & Expected heterozygosity $(\mathrm{He})$ & 0.693 & 0.638 \\
\hline & Fixation index (Fis) & 0.929 & 0.923 \\
\hline & p-value of Hardy-Weinberg (HW) & 0.000 & 0.000 \\
\hline \multirow{7}{*}{ Pg14 } & Allele size range (bp) & $279-291$ & $279-291$ \\
\hline & Number of sample (N) & 40 & 40 \\
\hline & Number of allele (A) & 5 & 5 \\
\hline & Observed heterozygosity (Ho) & 0.550 & 0.450 \\
\hline & Expected heterozygosity (He) & 0.700 & 0.713 \\
\hline & Fixation index (Fis) & 0.217 & 0.372 \\
\hline & p-value of Hardy-Weinberg (HW) & 0.000 & 0.000 \\
\hline \multirow{4}{*}{ Mean } & (A) Number of allele (A) & 5 & 5 \\
\hline & Observed heterozygosity (Ho) & 0.420 & 0.495 \\
\hline & Expected heterozygosity $(\mathrm{He})$ & 0,702 & 0,702 \\
\hline & Fixation index (Fis) & 0.405 & 0.298 \\
\hline
\end{tabular}


7 alleles, followed by $\mathrm{Pg} 2$ and $\mathrm{Pg} 14$ loci with 5 alleles, $\mathrm{Pg} 3$ and Pg13 locus with (4 alleles), Pg14 (with 5 alleles) (Tabel 2). Allele size in Pg2 locus has the same expected size as the striped catfish in Vietnam (NaNakorn et al., 2006). The average numbers of alleles of the G-1 and G-2 populations were same (5.00). However, it was lower than Vietnam (5.2) (Na-Nakorn et al., 2006). The frequency of alleles for the same locus in each population varied indicating the G-1 and G-2 populations were formed from different genotype sources. The private alleles were not found in the G-1 and G-2 populations. All alleles found in the G-1 were inherited to the G-2 population (Table 2 and Figures 1).

A heterozygote deficit existed since the average of observed heterozygosity (Ho) was less than the expected one $(\mathrm{He})$ for all loci and generation levels $(p<0.05)$. A similar result was also found in the striped catfish populations (Na-Nakorn \& Moeikum, 2009), African catfish (Imron et al., 2011), tilapia (Gustiano et al., 2013), and common carp (Syahputra et al., 2016). The appearance of homozygote excess could be caused by a selection program (Allendorf \& Luikart, 2007; Garcia de Leon et al., 1997).

The apparent inbreeding levels in the G-1 and G-2 populations were also signaled by the average FST index fixation (inter-population fixation index) and FIT (total population fixation index). Table 3 showed that the mean values of FIS, FST, and FIT fixation indices were all positive.
The results of genetic variation analysis using AMOVA showed that the genetic variation in the G-1 and G-2 populations of fast-growing striped catfish was more due to the genetic variation within and among the individuals and genetic variation among individuals in each generation with the percentages of $63.02 \%$ and $34.21 \%$ respectively. The genetic differentiation between populations only contributed a small proportion $(2.77 \%$ to the genetic variation of both fast-growing striped catfish generations (Table 4).

In this study, the striped catfish populations had relatively low genetic variation. This result suggests that monitoring of genetic variation and scheme of good spawning are needed on the next selection program to produce fast-growing striped catfish. Based on the research findings, better spawning schemes and improving the aquaculture techniques on the selection program should be considered to avoid inbreeding depression.

\section{CONCLUSION}

The five microsatellite loci used were polymorphic in the G-1 and G-2 populations of fast-growing striped catfish. The genetic diversity between the $\mathrm{G}$ 1 and G-2 populations has few differences. In addition, there was a deficit of heterozygosity in both populations. Inbreeding occurred in both populations, and the G-1 population had a higher inbreeding level than that of the G-2 population. Genetic variation in

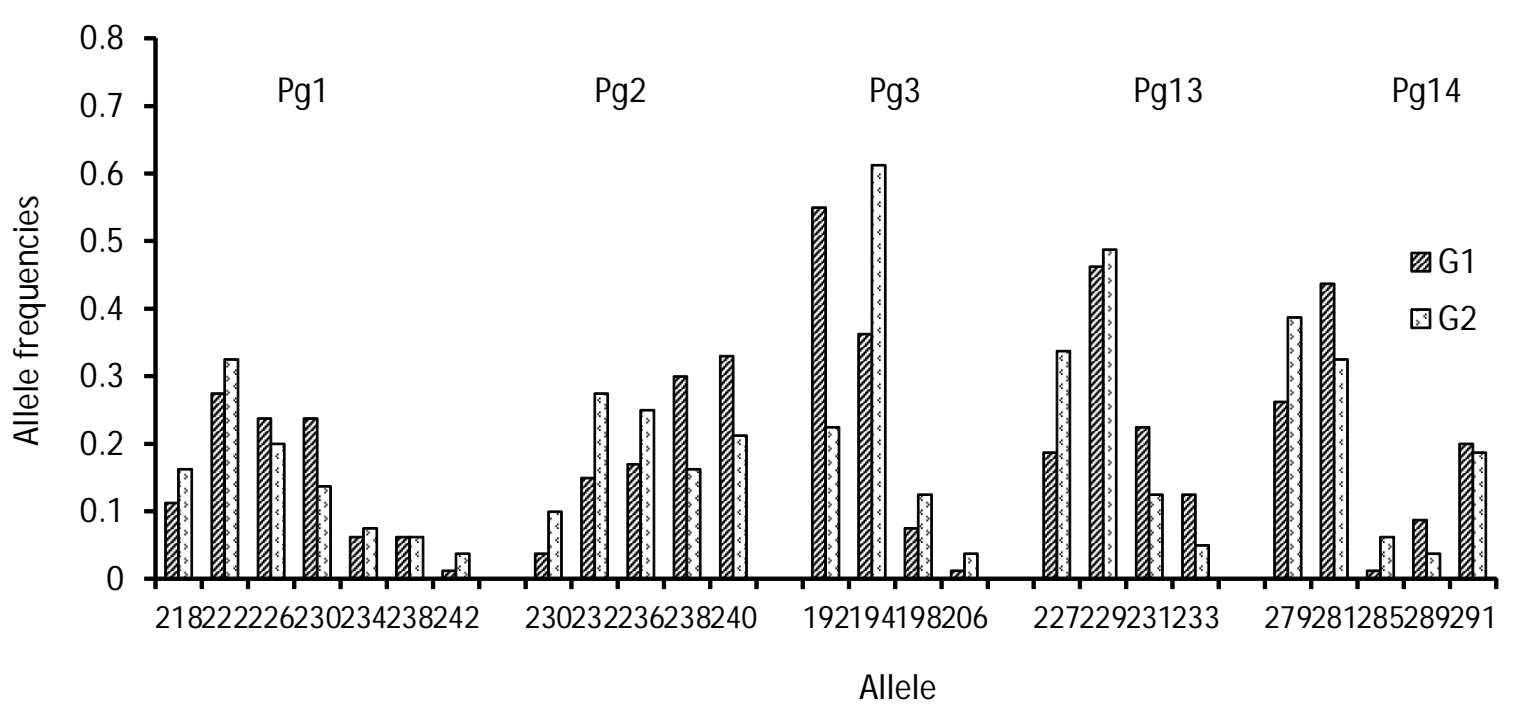

Figure 1. Number and distribution of alleles frequencies in G-1 and G-2 of fast-growing striped catfish at each microsatellite locus. 
Table 3. The f-statistic value in the G-1 and G-2 populations of fast-growing striped catfish

\begin{tabular}{cccc}
\hline Loci & Fis $_{\text {IS }}$ & Fs $_{\text {T }}$ & $\mathbf{F}_{\mathbf{T}}$ \\
\hline Pg1 & 0.199 & 0.001 & -0.198 \\
Pg2 & 0.289 & 0.022 & 0.304 \\
Pg3 & 0.605 & 0.115 & 0.651 \\
Pg4 & 0.926 & 0.005 & 0.926 \\
Pg5 & 0.295 & 0.007 & 0.300 \\
Average & 0.344 & 0.027 & 0.344 \\
\hline
\end{tabular}

Table 4. The Analysis of molecular variance (AMOVA) in the G-1 and G-2 populations of fastgrowing striped catfish

\begin{tabular}{lcccc}
\hline \multicolumn{1}{c}{ Source of variation } & db Sum of squares & $\begin{array}{c}\text { Variance } \\
\text { components }\end{array}$ & $\begin{array}{c}\text { Percentage of } \\
\text { variation }\end{array}$ \\
\hline Among generation & 1 & 6.406 & 0.05 & 2.77 \\
Among individuals within generation & 78 & 186.062 & 0.62 & 34.21 \\
Within populations & 80 & 91.50 & 1.14 & 63.02 \\
\hline \multicolumn{1}{c}{ Total } & 159 & 283.97 & 1.81 & \\
\hline
\end{tabular}

the G-1 and G-2 generations of fast-growing striped catfish was more due to genetic variation in individuals and genetic variation among the individuals in the population than in the genetic differentiation between populations.

\section{ACKNOWLEDGEMENTS}

The research was supported by the funding from APBN 2016 and 2017 of the Research Institute for Fish Breeding, Sukamandi. We thank Ika Nurlela, Kamlawi, Arsyad Tirta Subangkit, Ahmad Suryana, and other researchers for their help in this research.

\section{REFERENCES}

Allendorf, F.W., \& Luikart, G. (2007). Conservation and the genetics of populations. Malden, Massachusetts, USA: Blackwell Publishing.

Bui, T.M., Phan, L.T., Ingram, B.A., Nguyen, T.T.T., Gooley, G.J., Nguyen, H.V., Nguyen, P.T., \& Silva, S.S.D. (2010). Seed production practices of striped catfish, Pangasianodon hypophthalmus in the Mekong Delta region, Vietnam. Aquaculture, 306, 92-100.

Chistiacov, D.A., Hellemans, B., \& Volckaert, F.A.M. (2005). Microsatellites and their genomic distri- bution, evolution, function and applications: A review with special reference to fish genetics. Aquaculture, 255, 1-29.

Directorate of Aquaculture. (2016). Indonesian aquaculture profile. Ministry of Marine Affairs and Fisheries. Jakarta, $37 \mathrm{pp}$.

Das, P., Barat, A., Meher P.K., Ray, P.P., \& Majumdar, D. (2005). Isolation and characterization of polymorphic microsatellites in Labeorohita and their cross-species amplification in related species. Molecular Ecology Notes, 5(2), 231-233.

Excoffier, L., Laval, G., \& Schneider, S. (2006). Arlequin ver. 3.0: An integrated software package for population genetics data analysis. Evolutionary Bioinformatics Online, 1, 47-50.

Food Agriculture Organization [FAO]. (2016). The State of World Fisheries and Aquaculture. Fisheries and Aquaculture Department. www.FAO.org.

Garcia de Leon, F.J., Chikhi, L., \& Bonhomme, F. (1997). Microsatellite polymorphism and population subdivision in natural population of European sea bass, Dicentrarchuslabrax (Linnaeus, 1758). Molecular Ecology, 6(1), 51-62.

Gustiano, R., Kusmini, I.I., Iskandariah, Arifin, O.Z., Huwoyon, G.H., Ath-thar, M.H.F. (2013). Herita- 
bility, response selection and genotype using RAPD on F3 of nile tilapine. J. Ris. Akuakultur, 8(3), 347-354.

Goudet, J. (2001). FSTAT, A Program to estimate and test gene diversities and fixation indices, version 2.9.3. Available from http://www.unil.ch/izea/ softwares/fstat.html.

Ha, P.H., Nguyen, T.T.T., Poompuang, S., \& Na-Nakorn, U. (2009). Microsatellites revealed no genetic differentiation between hatchery and contemporary wild populations of striped catfish, Pangasianodon hypophthalmus (Sauvage 1878) in Vietnam. Aquaculture, 291, 154-160.

Hughes, R.A., Inouye, B.D., Johnson, M.T.J., Underwood, N., \& Vellend, M. (2008). Ecological consequences of genetic diversity. Ecol. Lett., 11, 609-623.

Imron, Sunandar, D., \& Tahapari, E. (2011). Microsatellite genetic variation in cultured populations of African catfish, Clarias gariepinus in Indonesia. Indonesian Aquaculture Journal, 6(1), 1-10.

Na-Nakorn, U., \& Moeikum, T. (2009). Genetic diversity of domesticated stocks of striped catfish, Pangasianodon hypophthalmus (Sauvage 1878) in
Thailand: Relevance to broodstock management regimes. Aquaculture, 297, 70-77.

Na-Nakorn, U., Sriphairoj, K., Sukmanomon, S., Poompuang, S., \& Kamonrat, W. (2006). Polymorphic microsatellite from DNA of the endangered Mekong giant catfish, Pangasianodon gigas (Chevey) and cross-species amplification in three species of Pangasius. Molecular Ecology Notes, 6, 1174-1176.

Park, L.K., \& Moran, P. (1994). Developments in molecular genetic techniques in fisheries. Rev. Fish Biol. Fish, 4, 272-99.

So, N., Maes, G.E., \& Volckaert, F.A.M. (2006). High genetic diversity in cryptic populations of the migratory sutchi catfish Pangasianodon hypophthalmus in the Mekong River. Heredity, 96, 166-174.

Syahputra, K., Ariyanto, D., \& Hayuningtyas, E.P. (2016). Genetic diversity in $F_{0}$ and $F_{1}$ populations of Rajadanu strain of common carp, Cyprinus carpio resistance to KHV (Koi herpesvirus) using three microsatellite loci. J. Ris. Akuakultur, 11(1), 59-66.

Zane, L., Bargelloni, L., \& Patarnello, T. (2002). Strategies for microsatellite isolation: a review. Molecular Ecology, 11(1), 1-16. 